\title{
A process model of voluntary travel behavior modification and effects of Travel Feedback Programs (TFPs)
}

by

Ayako Taniguchi, Ph.D. Eng.

Assistant Professor

Department of Risk Engineering, University of Tsukuba

1-1-1, Ten-noh-dai, Tsukuba, Ibaraki 305-8573, Japan

Tel: +81-(0)29-853-5754

Fax: +81-(0) 29-853-5754

E-mail: taniguchi@risk.tsukuba.ac.jp

and

Satoshi Fujii, Ph.D. Eng.

Professor

Department of Civil Engineering, Tokyo Institute of Technology

2-12-1, Ookayama, Meguro, Tokyo 152-8552, Japan

Tel: +81-(0)3-5734-2590

Fax: +81-(0)3-5734-2590

E-mail: fujii@plan.cv.titech.ac.jp

Total number of words: $4,574+250 * 7$ items $=6,324$ words 


\begin{abstract}
This study tested an integrated process model of travel behavior modification. We used a model that combined the theory of planned behavior (TPB), norm activation theory (NAT), a theory of implementation intention, and theories of habit. To test the integrated model, we used panel data $(\mathrm{n}=208)$ obtained before and after travel feedback programs (TFPs); the TFP is a communication program aimed at voluntary travel behavior modification, from automobile use to non-auto means of travel such as public transit and bicycle use. A structural equations model using the data collected tested the integrated model. The results showed that habit prevents people from forming behavioral intentions for behavior change; behavior change is induced by implementation intentions, which are, in turn, influenced by behavior intentions; and behavioral intentions are influenced by altruistic determinants rather than by non-altruistic determinants.
\end{abstract}

KEYWORDS: Habit, implementation intention, norm activation theory, theory of planned behavior, TFP, travel feedback program, voluntary travel behavior modification 


\section{INTRODUCTION}

To ease traffic congestion in urban areas, and to reduce environmental problems resulting from automobile emissions, transport policy makers have begun to implement mobility management measures ${ }^{12}$. Mobility management is intended to influence individual awareness and certain psychological factors in order to encourage voluntary behavior change. Mobility management includes the provision of specific information on public transit, as well as the development of travel campaigns, and travel education. A typical program might involve participants reporting their travel behavior or requesting necessary information for travel behavior change; they might also receive feedback that would include information on the $\mathrm{CO} 2$ emissions their car produces, advice on how to reduce car use, and individualized information on public transit that could be used as an alternative. Examples of such programs include Individualized Marketing ${ }^{3)}$, Travel Smart ${ }^{4)}$, Travel Blending ${ }^{5)}$ ) , and the Wise Way to Use a Car Program ${ }^{7)}{ }^{8)}$. We have called these behavior modification programs 'travel feedback programs' $\left(\right.$ TFP) ${ }^{8)}$.

Travel feedback programs have been widely implemented in EU countries, in Australia, and in Japan, and have reduced car use by about $7 \%$ to $15 \%$ among those participating in EU countries and in Australia ${ }^{1)}$ and by $19 \%$ (the average of 10 TFP cases) among those participating in Japan ${ }^{9)}$. However, it is not well understood how travel feedback programs actually modify travel behavior. If we could understand how travel behavior changes as a result of travel feedback programs, the development of more effective and efficient programs for travel behavior modification, from car use to pro-environmental means of transport, would be facilitated.

In order to understand the process of voluntary travel behavior modification, from car use to public transit use, we examined various theories about behavior and attitude, including Ajzen's theory of planned behavior ${ }^{10)}$, norm activation theory ${ }^{11)}$, a theory of implementation intention $^{12) 13)}$, and theories of habit ${ }^{14)}{ }^{15)}{ }^{16)}$.

It should be noted that to our knowledge, these theories have not previously been applied together to describe the process of voluntary travel behavior change, although each theory has been used to provide a partial explanation of the process of voluntary travel behavior modification $\left.{ }^{8)} 14\right)$ 16) 17). With this in mind, we proposed and investigated an integrated process model of voluntary travel behavior change, as shown in Figure 1, which incorporated the theory of planned behavior, norm activation theory, a theory of implementation intention and theories of habit. By evaluating this integrated model using empirical data, we hoped to gain an understanding of which determinants were more important for voluntary travel behavior change. Statistical analysis based on such an integrated process model might indicate which determinants are more important for activating behavioral intention for travel behavior change, and which less so, for example, non-altruistic determinants assumed in theory of planned behavior or altruistic determinants assumed in norm activation theory. In addition, such analysis might indicate which aspects of habitual car use have negative impacts on behavioral intention, implementation intention, and actual behavior. Such findings might be helpful in designing more effective travel feedback programs in the future.

Dynamic data about travel behavior and psychological variables obtained before and after travel feedback programs are more helpful in this respect than the cross sectional data used for testing theoretical models or behavioral hypotheses about travel mode choice, because they are more suitable for testing causality. Analysis of the process of voluntary travel behavior modification resulting from TFP is useful for a theoretical understanding of travel behavior, and for developing better travel feedback programs for practical mobility management. Therefore, we used panel data obtained from two surveys, one implemented before and one after the intervention that was conducted to test the model.

Figure 1 
Figure 1 shows the integrated model for car use reduction that was tested in this study. The model shows the assumption that the behavior of car use reduction is influenced by the behavioral intention to reduce automobile use, and that behavioral intention is, in turn, influenced by psychological factors, which include attitude and perceived behavioral control. These factors are considered in the theory of planned behavior, one of the most widely used behavioral theories ${ }^{18)}$.

Although the theory of planned behavior refers to non-altruistic behavior, voluntary travel behavior modification, from car use to public transit use, may be encouraged by altruistic motivations, as is hypothesized in norm activation theory. According to norm activation theory, behavior is influenced by an awareness of the negative consequences of car use. The model shows three types of awareness of consequences (social, biosphere, and general), and a general environmental concern that may be related to an awareness of consequences ${ }^{19)}$; these concerns, as motivators, could be determinants of behavioral intention.

Other determinants of behavioral intention include an injunctive subjective norm, a descriptive subjective norm, the perceived beliefs of family members regarding the necessity of car use, and an individual's beliefs regarding the necessity of car use. The first three are all related to social pressure ${ }^{20)}$ and may have a similar effect to the subjective norm assumed in the theory of planned behavior. The injunctive subjective norm refers to the belief that others, such as family members, have a moral obligation to reduce car use, whereas the descriptive subjective norm refers to the belief that others, such as family members, agree with the target individual's car use reduction.

\section{Implementation Intention}

Behavioral intention is necessary for sustained car use reduction, but it is not sufficient. In the real world, travel behavior is not always modified, in spite of an intention to do so. In an attempt to determine how intentions are implemented in behavior, Heckhausen and Gollwitzer ${ }^{21)}$ and Gollwitzer ${ }^{12)}{ }^{13)}$ made a distinction between 'goal intention' and 'implementation intention'. While goal intention can be regarded as a behavioral intention ${ }^{22)}{ }^{23)}$, implementation intention entails a plan for when, where, and how to implement the target behavior. Gärling and Fujii ${ }^{22)}$ hypothesized that the effect of behavioral intention on behavior is mediated by implementation intention. They used data on causal relations between behavioral intention, implementation intention or planning, and actual behavior to support this assumption.

Habit

In order to understand travel behavior modification, it is necessary to consider habit. Studies have suggested that the habit of using a car prevents travel behavior modification, from car use to alternative travel modes ${ }^{14)}{ }^{15)}{ }^{16}$. The authors hypothesized that behavioral intention, implementation intention, and behavior are weakened by a habit of car use.

Figure 2

\section{METHOD}

In order to test our model of travel behavior modification, we used data obtained from a twowave panel survey, conducted before and after a travel feedback program implemented in an elementary school in Sapporo, Japan. Sapporo city is a government-ordinance-designated city, with a population of approximately 1.8 million. There are three subway lines and a full bus network. The vehicle trip share is about 40 to 50\%. The target elementary school was located in a suburban area, with buses arriving every five minutes at peak times, and a subway station fifteen minutes away. Students commuted on foot, but in case of rain, their parents would often transport them by car. Almost all students came from car-owning households. The participants in the travel feedback program included fifth grade students (10-11 year olds) and their family members (age of participants were $28 \%$ on twenties, $63 \%$ on thirties, and $9 \%$ on fifties; and ratio of female was almost half). The survey included 208 family members out of 398 (response rate was 52\%), and the data collected only family members were used to test the model. 
In the experiment, four classes in the elementary school participated in two different types of travel feedback program. Students in two classes, as well as members of their families, received individualized information and advice on how to reduce their car use. This group is referred to as the 'advice group'. Students in the other two classes, as well as members of their families, were asked to make behavioral plans that would reduce their car use. This group is referred to as the 'planning group' (see Figure 2). Details of analysis comparing those two groups were reported at Fujii \& Taniguchi ${ }^{24)}$.

Six weeks prior to the experimental intervention, the students and their families answered a questionnaire in which the model's psychological factors were measured. Data for the factors, except habit, were obtained using five-point scales, in which the most proenvironmental end was calibrated as five and the other end was calibrated as one. Exact wordings and scale antipodes used for measuring factors are shown in Table 1. Verplanken et al. developed a way to measure habit ${ }^{25)}{ }^{26)}$, a method we used in the questionnaire.

Table 1

Four weeks before the intervention, all the students were given lessons as lecture 1 on the issue of global warming, the role of $\mathrm{CO} 2$ in this problem, and levels of $\mathrm{CO} 2$ emissions resulting from car use.

One week after the lecture 1, all the families in the advice group filled in a three-day activity-travel diary. Participants logged start times, end times, types and locations of all their activities, as well as the mode of transportation used to travel to and from these activities. After receiving their diaries, we made diagnostic checklists ${ }^{7)}{ }^{8)}$ for each family, in which their threeday activity-travel patterns were graphically presented, and the number and length of their journeys by each mode of travel were recorded, along with comments that included suggestions on how the participants' activity-travel patterns might be modified to reduce $\mathrm{CO} 2$ emissions. Diagnostic checklists were then given to each family in the second lesson as lecture 2, to encourage the reduction of car use. Three weeks after the diary survey, in the lecture 2, students participating in the advice group received diagnostic checklists for themselves and their families. Using the diagnostic checklists, students calculated their own and their families' $\mathrm{CO} 2$ emissions. The $\mathrm{CO} 2$ emissions for the whole class were also calculated and confirmed. Finally, they learned the easy ways to reduce $\mathrm{CO} 2$ emissions caused by car-use, such as "Change travel mode", "Change destination", "Combine errands, and reduce the number of times the car is used".

In the planning group's second lesson as lecture 2, students developed behavioral plans to modify their families' car use and increase more sustainable travel modes. In their lesson, bus and train maps and timetables were distributed and students considered concrete ways to modify their travel behavior. Following the lecture 2, students brought their behavioral plan sheets home, and each family was asked to develop behavioral plans to modify home-based car trip chains with the goal of reducing $\mathrm{CO} 2$ emissions. They were instructed to develop behavioral plans to modify up to three of their car trip chains. Families filled out questionnaires describing planned departure times, arrival times, and travel modes for each trip, as well as the locations of each stop in their modified car trip chains. This intervention took place on the same day as the intervention for the advice group.

Two weeks after the second lesson, participants filled out an exact duplicate of the original questionnaire they had filled out six weeks before the intervention.

The third lesson as lecture 3 was held one month after the second. In the lecture 3, students received their results comparing the before and after questionnaires, discussed their efforts to reduce car use, and considered what more could be done to reduce $\mathrm{CO} 2$ emissions further in the future.

Students' families did not attend the lessons, but did commit to answering the questionnaires presented before and after the intervention, to filling in a travel diary for three days, and to making a behavioral planning sheet with their children. Through these activities, 
the program aimed to have an effect not only on the participating children but also on their families.

\section{RESULTS}

Table 2 shows mean (M) and standard deviations (STD) for factors in both surveys, and $t$ statistics for differences between the pre- and post-travel feedback program. This table shows that awareness of consequences (general), awareness of consequences (social), and the subjective norm (injunctive) significantly increased. It also shows that behavioral intentions, implementation intentions, and pro-environmental behavior increased significantly. These results suggest that the travel feedback program encouraged attitude and behavior modifications in a pro-environmental direction.

Table 2

We previously reported statistical tests of the effectiveness of the travel feedback programs in this experiment, and performed a comparative analysis of the effectiveness of different types of travel feedback program ${ }^{24)}$ 27). The effectiveness of travel feedback programs on psychological variables such as behavioral intention and awareness of consequences was not significantly different for the planning and advice groups, but car use reduction, as measured by frequency of car use and range of travel time over three days, was significantly larger for the planning group than for the advice group.

The primary objective of the present study was to test the structural relationships shown in Figure 1, rather than to test the effectiveness of travel feedback programs or make a comparative analysis between planning and advice groups as done previously ${ }^{24)}{ }^{27)}$. However, one might expect structural relationships to differ between the advice and planning groups. Therefore, before we tested the structural relationships shown in Figure 1 using data from this experiment, we estimated structural equations models separately for the advice and planning groups. However, we did not find any significantly different coefficients across the two models. Therefore, we decided to use only one model. However, the model included a dummy variable to indicate the difference between two types of travel feedback program, since we had already found that car use reduction differed across the two models, as shown in Fujii and Taniguchi ${ }^{24}$ and Taniguchi et al. ${ }^{27}$.

In order to test structural relationships, we determined change variables for pre- and post-travel feedback program interventions. The change variables were then used to estimate a structural equations model, shown in Figure 1. The results from the structural equations model using these change variables are more suitable than are results from cross-sectional data for assessing causal relations between variables.

In the structural equations analysis, paths from dummy coded variables indicating the type of travel feedback program for all the variables were also estimated in addition to paths shown in Figure 1. We also estimated constant terms for all the variables. Since constant terms for change variables indicate the changes occurring from pre- to post-travel feedback program periods, these can be regarded as direct effects of the travel feedback program's implementation.

The result of structural equations analysis can be seen in Table 3 and Table 4 . Table 3 shows estimated path coefficients and their t-statistics, and Table 4 shows estimated direct effects of the travel feedback program's implementation. Figure 3 gives a graphic representation of the significant paths reported in Table 3 and Table 4. With respect to total goodness of fit to the data, NFI is 0.749 , CFI is 0.837 , and RMSEA is $0.073^{1}$. Although these indexes may not be satisfactory, $\chi 2[n=208$; degree of freedom $=75]$ is 157.6 , which indicated that the goodness of fit of the model is acceptable when judged by conventional criteria ${ }^{28)}{ }^{29}$.

\footnotetext{
${ }^{1}$ NFI represent Normed Fit Index, CFI represent Comparative Fit Index, RMSEA represent Root Mean Square Error of Approximation. See Jöreskog, K. G., \& Sörbom, D. (1993) ${ }^{30)}$ about details of these indexes.
} 
This implies that the data lend a support of the proposed model show in Figure 1 that integrated theory of planned behavior, norm activation theory and theories for implementation intention and habit.

Table 3

Table 4

Figure 3

According to Table 3 and Figure 3, behavior change for car use reduction was significantly induced by implementation intention, which was caused, in turn, by behavioral intention. This supports the hypothesis of a mediating effect for implementation intention, between behavioral intention and behavior.

The results show that behavioral intention is significantly influenced by awareness of consequence (biosphere), awareness of consequence (general), and general environmental concern. Attitude, perceived behavioral change, subjective norms, and necessities did not significantly influence behavioral intention, so norm activation theory may be more suitable for describing voluntary travel behavior change than behavioral hypotheses, assuming non-altruistic motivations, as posited by the theory of planned behavior.

The results also show that habits have a negative effect on behavioral intention. This supports the hypothesis that habits impede behavioral change. This travel feedback program seemed to significantly and directly activate both behavioral intention and implementation intention. This program seemed to have a positive effect on subjective norms, but subjective norms had no effect on any factors assumed in the model.

Finally, according to Table 4 and Figure 3, a dummy coded variable on the type of travel feedback program had a significant effect on the subjective norm (descriptive), but had no effect on any other variables. So, travel feedback programs in which participants receive advice on how to reduce car use seem to be as effective, with respect to behavior and attitude modification, as programs in which participants are requested to make a behavioral plan on how to reduce their car use.

\section{DISCUSSION}

\section{Behavior, Intentions and Habit}

The dynamic data obtained from the panel survey before and after the travel feedback program confirmed the hypothesis that car use reduction is caused by an implementation intention to reduce car use, and that the implementation intention is, in turn, caused by a behavioral intention to reduce car use. These results support those from previous studies ${ }^{22)}{ }^{23)}$.

It appears that habitual car use has a negative effect on behavioral intention. This supports studies that found habit impeded behavioral modification ${ }^{14)}{ }^{15)}{ }^{16)}$. However, these studies discussed other consequences of habit; for example, they showed that habit reduces the consistency between behavioral intention and behavior. Although this study did not focus on intention-behavior consistency, but was rather an investigation of direct effects between variables, an analysis on intention-behavior consistency is necessary for a more comprehensive understanding of the effects of habit on behavior modification.

\section{Determinants of Behavioral Intention}

The analysis indicated that increased awareness of consequences for the biosphere, a general awareness of the consequences of car use, and a general environmental concern all had a 
positive effect on behavioral intention to reduce car use. These results support the causal relations hypothesized in norm activation theory. On the other hand, changes in attitude toward car use and perceived behavioral control had no effect on behavioral intentions. In addition, changes in beliefs about the necessity of car use and subjective norms had no effect on behavioral intentions. These results do not support the causal relations hypothesized in the theory of planned behavior. Thus, norm activation theory can better explain the motivation for voluntary travel behavior change than the theory of planned behavior. Voluntary travel behavioral modification might be encouraged by altruistic motivation, such as awareness of consequences, as opposed to non-altruistic motivation.

Similar results were reported in Gärling et al. $(2003)^{31)}$, who found that proenvironmental behavioral intentions (e.g., contribution of money to an environmental organization, or signing a petition in support of environmental laws) were significantly influenced by factors hypothesized in norm activation theory, but were not influenced by awareness of egoistic consequences. They pointed out that since the theory of planned behavior (assuming that concerns of self-interest are the determinants of intention) had received substantial empirical support ${ }^{18)}$, it has been suggested that pro-environmental behavior might differ from other behavior that has been studied. Our results also suggest that individuals who voluntarily modify their travel behavior may not be displaying self-interest, but may be displaying altruistic behavior, as well as other types of pro-environmental behavior, such as those investigated in Gärling et al. (2003) ${ }^{31)}$ and in other, similar studies $\left.{ }^{32)} 33\right)^{34)}{ }^{35}$ ).

\section{Policy Implications}

Participants' behavioral intentions and implementation intentions appeared to increase after participation in the travel feedback program. The increase did not differ according to the different types of travel feedback program, i.e., the program that involved participants making a behavioral plan on how to reduce car use, and the program that provided individual advice on how to reduce car use. These results clarify why travel feedback programs have been so effective in reducing car use ${ }^{1)-8}$. Travel feedback programs have positive direct effects on both behavioral intentions and on implementation intentions and these changes in these forms of intention are expected to reduce car use. The direct effect on behavioral intentions may be due to the fact that travel feedback programs always provide an opportunity to choose between different means of travel. The direct effect on implementation intentions may be due to the fact that travel feedback programs provide specific information on how to reduce car use or on how to use alternative means of transport, such as trains and buses.

Travel feedback programs consist of many different types of intervention, including the provision of information on how to use alternative means of travel; the provision of information intended to persuade participants not to use their car, and the request that participants make behavioral plans on how to reduce car use. Although this study indicates that the kind of intervention used in this travel feedback program made no difference to the travel behavior modification that occurred, other types of interventions may have other effects. In order to develop more effective and efficient programs, further empirical studies are needed to identify those methods that are most effective for modifying specific psychological variables.

\section{REFERENCES}

1) Jones, P. (2003) Encouraging Behavioural Change Through Marketing and Management: What can be achieved?, Presented at 10th International Conference on Travel Behavior Research, Lucerne, Switzerland.

2) Cairns, S., Sloman, L., Newson, C., Anable, J., Kikbride, A., and Goodwin, P. (2004) Smarter choices: Changing the way we travel, Department for Transport, UK.

3) Brög, W. (1998) Individualized Marketing: Implications for TDM. CD-ROM of Proceedings: 77th Annual Meeting of Transportation Research Board.

4) Department of Transport, Western Australia (2000) Travel Smart: A cost-effective contribution to transport infrastructure. 
5) Ampt, E., and Rooney, A. (1999) Reducing the Impact of the Car - A Sustainable Approach, Travel Smart Adelaide. 23rd Australasian Transport Forum, Perth, Australia, September 29-October 1.

6) Rose, G., and Ampt, E. (2001) Travel blending: an Australian travel awareness initiative. Transportation Research, 6D, 95-110.

7) Taniguchi, A., Hara, F., Takano, S., and Kagaya, S. (2002) Study of Traffic Environment Awareness among Elementary Schoolers in Japan, and a Program to Raise It. Traffic and Transportation Studies, K.C.P. Wang, G. Xiao, L. Nie, and H. Yang (Eds.), Vol. 1. Pp. 916.

8) Taniguchi, A., Hara, F., Takano, S., Kagaya, S., and Fujii, S., (2003) Psychological and behavioral effects of Travel Feedback Program for travel behavior modification, Transportation Research Record, 1839, 182-190.

9) Fujii, S., and Taniguchi, A. (2006) Determinants of the effectiveness of travel feedback programs - a review of communicative mobility management measures for changing travel behaviour in Japan, Transport Policy, 13 (5), pp. 339-348.

10) Ajzen, I. (1985) From intentions to actions: A theory of planned behavior. In J. Kuhl and J. Beckmann (Eds.), Action control: From cognition to behavior. Heidelberg: Springer. Pp. 11-39.

11) Schwarz, S.H. (1977) Normative influences on altruism. In: L. Berkowitz (Ed.), Advances in experimental psychology, vol. 10. New York: Academic Press. Pp. 222-280.

12) Gollwitzer, P. M. (1993) Goal achievement: The role of intentions. European Review of Social Psychology, 4, 141-185.

13) Gollwitzer, P. M. (1996). The volitional benefits of planning. In P. M. Gollwitzer and J. A. Bargh (Eds), The psychology of action: Linking cognition and motivation to behavior (pp. 287-312). New York: Guilford Press.

14) Gärling, T., Fujii, S., and Boe, O. (2001) Empirical tests of a model of determinants of script-based driving choice. Transportation Research, F 4, 89-102.

15) Ronis, D.L., Yates, J.F., and Kirscht, J.P. (1989) Attitudes, decisions, and habits as determinants of repeated behavior. In: A.R. Pratkanis, S.J. Breckler, and A.G. Greenwald (Eds.), Attitude structure and function. Hillsdale, NJ: Erlbaum. Pp. 213-239.

16) Verplanken, B. and Aarts, H. (1999) Habit, attitude and planned behaviour: Is habit an empty construct or an interesting case of goal-directed automatic? European Review of Social Psychology, 10, 101-134.

17) Fujii, S., and Gärling, T. (2003) Development of script-based travel mode choice after forced change, Transportation Research F, 6 (2), 117-124.

18) Conner, M., and Armitage, C.J. (1998) Extending the theory of planned behavior: A review and avenues for further research. Journal of Applied Social Psychology, 28, 1429-1464.

19) Fransson, N., and Gärling, T. (1999) Environmental concern: Conceptual definitions, measurement methods, and research findings. Journal of Environmental Psychology, 19, 369-382.

20) Snyder, M., and Stukas, A.A. (1998) Interpersonal processes: The interplay of cognitive, motivational, and behavioral activities in social interaction, Annual Review of Psychology, 50, 273-303.

21) Heckhausen, H., and Gollwitzer, P.M. (1987) Thought contents and cognitive functioning in motivational versus volitional states of mind. Motivation and Emotion, 11, 101-120.

22) Gärling, T., and Fujii, S. (2002) Structural equation modeling of determinants of planning. Scandinavian Journal of Psychology, 43 (1), 1-8.

23) Fujii, S. (2005) Reducing inappropriate bicycle-parking through persuasive communication, Journal of Applied Social Psychology, 35(6), pp. 1171-1196.

24) Fujii, S., and Taniguchi, A. (2005) Reducing family car use by providing travel advice or requesting behavioral plans: An experimental analysis of travel feedback programs, Transportation Research D, 10 (5), 385-393.

25) Verplanken, B., Aarts, H., Van Knienbertg, A., and Van Knienberg, C. (1994) Attitude versus 
general habit: Antecedents of travel mode choice, Journal of Applied Social Psychology, 24, 285-300.

26) Verplanken, B., Aarts, H., and Van Knippenberg, A. (1997) Habit, information acquisition, and the process of making travel mode choices. European Journal of Social Psychology, 27, 539-560.

27) Taniguchi, A., Hagihara, G., Fujii, S., and Hara, F. (2004) A development of travel feedback program incorporating behavioral planning method: A case study for educational program in elementary school. Infrastructure Planning Review, 21 (4), 10111018. (In Japanese with English abstract)

28) Fan, X., Thompson, B., and Wang, L. (1999) Effects of sample size, estimation methods, and model specification on structural equation modeling fit indexes, Structural Equation Modeling, 6, 56-83.

29) $\mathrm{Hu}$, L.T., and Bentler, P.M. (1995) Evaluating model fit, in R.H. Hoyle (Ed.), Structural Equation Modeling: Concepts, Issues and Applications, Thousand Oaks, CA: Sage. Pp. 76-99.

30) Jöreskog, K. G., and Sörbom, D. (1993). LISREL8: Structural equation modeling with the SIMPLIS command language. Mooresville, IN: Scientific Software.

31) Gärling, T., Fujii, S., Gärling, A., and Jakobsson, C. (2003) Moderating effects of social value orientation on determinants of proenvironmental behavior intention. Journal of Environmental Psychology, 23 (1), 1-9.

32) Stern, P.C., Dietz, T., and Black, J.S. (1986) Support for environmental protection: The role of social norms. Population and Environment, 8, 204-222.

33) Stern, P.C., Dietz, T., and Kalof, L. (1993) Value orientations, gender, and environmental concern. Environment and Behavior, 25, 322-348.

34) Stern, P.C., and Dietz, T. (1994) The value basis of environmental concern. Journal of Social Issues, 50(3), 65-84.

35) Van Liere, K. D., and Dunlap, R. E. (1978) Moral norms and environmental behavior: An application of Schwartz's norm-activation model to yard burning. Journal of Applied Social Psychology, 8, 174-188. 
Figure 1. Hypothesis of the integrated process model of travel behavior modification.

Figure 2. Procedure of Experiment "TFP".

Figure 3. Significant effects shown in the results of the structural equations model.

Table 1. Measurements of the participants' psychological factors and the endpoints of scales.

Table 2. Mean (M) and standard deviation (STD) for each psychological factor, and $p$ values for one-way analysis of variance (before vs. after survey) of psychological factors assumed in the integrated process model.

Table 3. Estimated results of path coefficients.

Table 4. Estimated direct effects of the effect of the travel feedback program on each factor. 


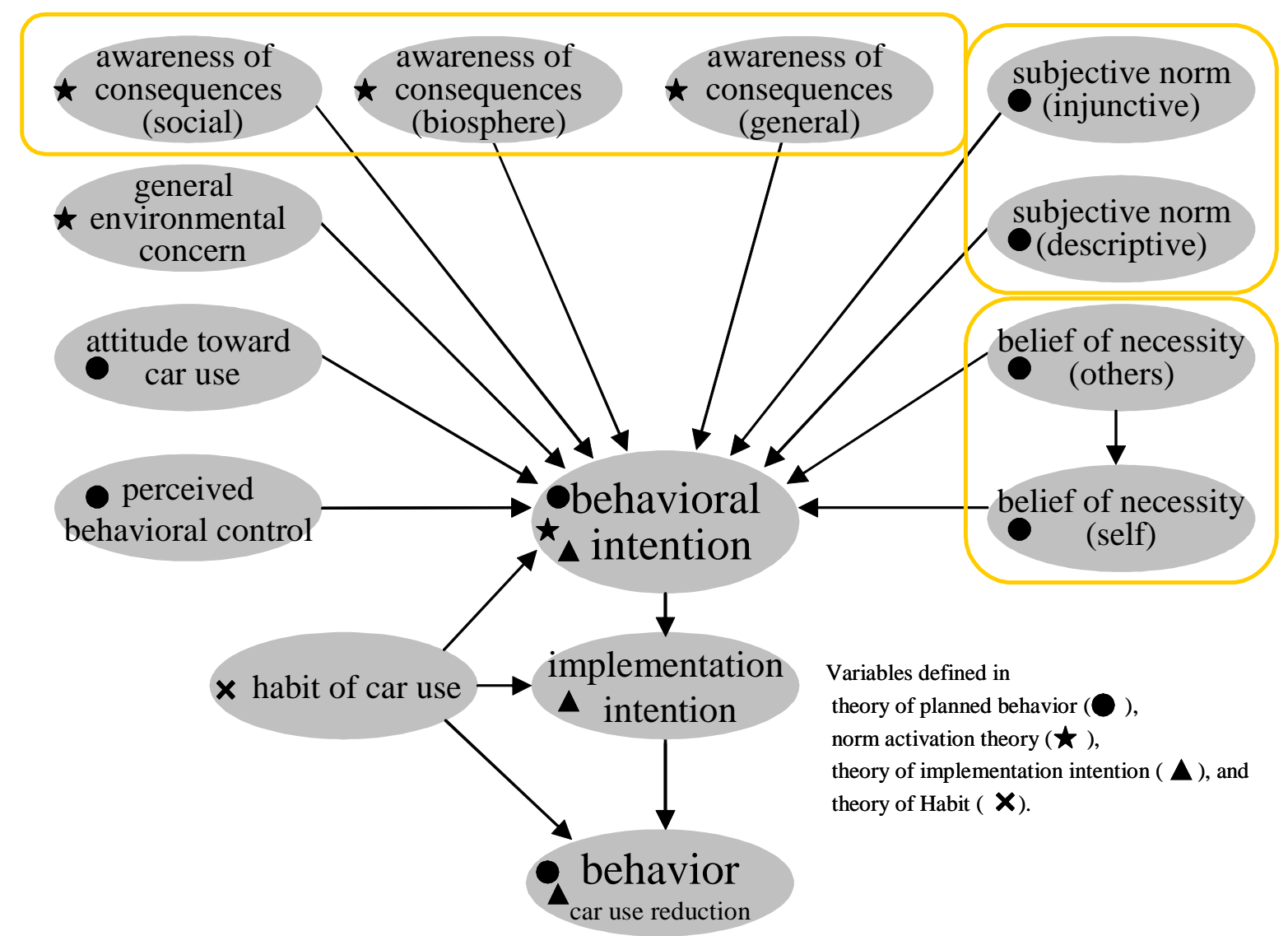

Figure 1. Hypothesis of the integrated process model of travel behavior modification. 


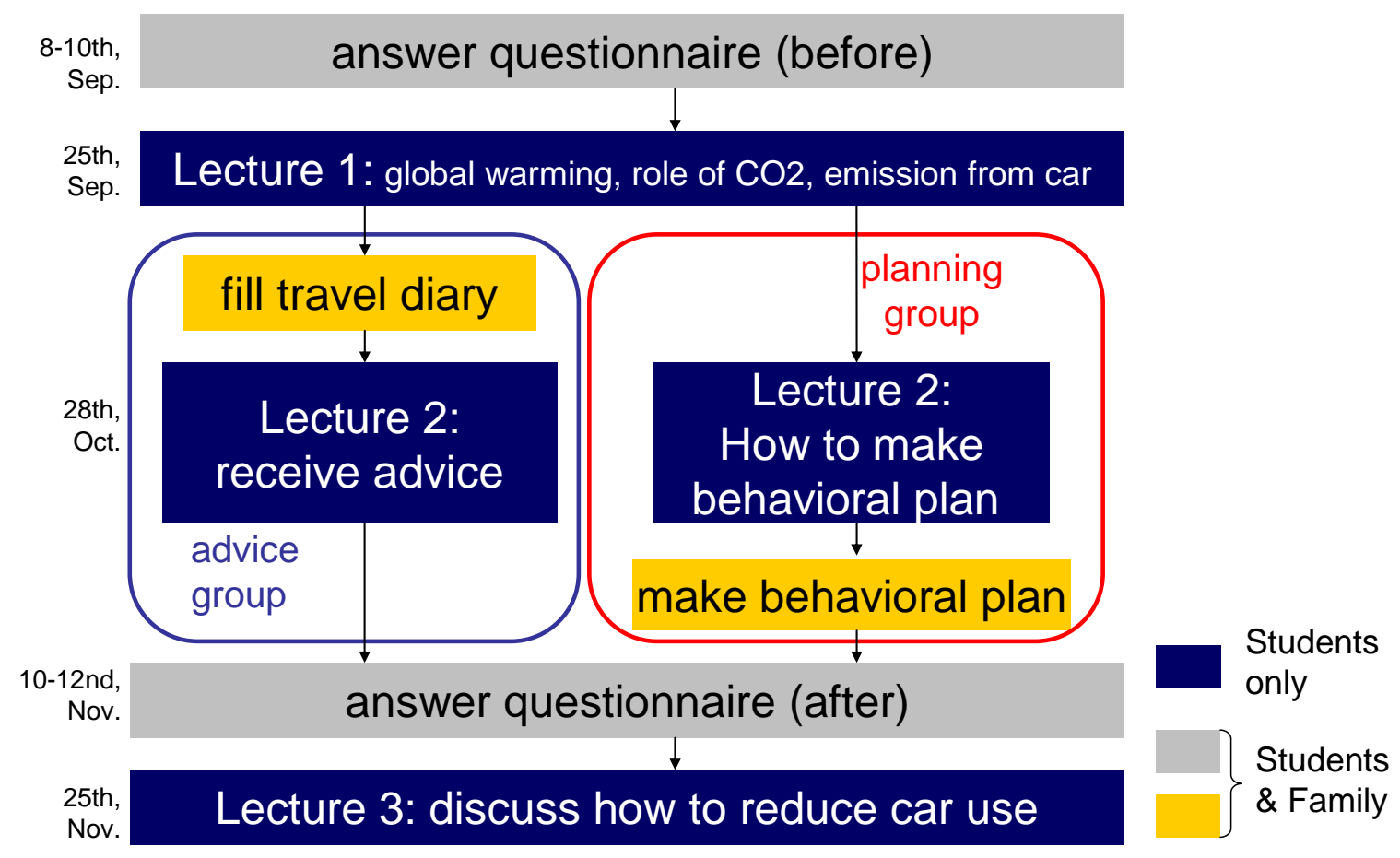

Figure 2. Procedure of Experiment "TFP". 
Table 1. Measurements of the participants' psychological factors and the endpoints of scales.

\begin{tabular}{|c|c|c|c|}
\hline Variable & Measurements & $\begin{array}{c}\text { Scale } \\
\text { antipodes }\end{array}$ & $\begin{array}{l}\text { Cronbach's } \alpha \\
\text { (before/after) }\end{array}$ \\
\hline habit & $\begin{array}{l}\text { Which transportation do you use } \\
\text { to visit a friend? } \\
\text { to shop for clothes? } \\
\text { to go to the movies? } \\
\text { to go for lunch? } \\
\text { to go out for dinner? } \\
\text { to go swimming? } \\
\text { to go skiing? } \\
\text { to go to the hospital? } \\
\text { to go to the convenience store? } \\
\text { to go to the bookstore? }\end{array}$ & $\begin{array}{l}\text { Family car, } \\
\text { Train, } \\
\text { Bus, Bicycle, } \\
\text { Walking, } \\
\text { Motorcycle, } \\
\text { Other }\end{array}$ & - \\
\hline $\begin{array}{l}\text { general } \\
\text { environmental } \\
\text { concern }\end{array}$ & $\begin{array}{l}\text { - Do you think you should think about } \\
\text { environmental problems? } \\
\text { - Are you concerned about environmental } \\
\text { problems? } \\
\text { - Do you think it is necessary for everyone to be } \\
\text { thoughtful about environmental problems? } \\
\text { - Do you think that we must pay attention to } \\
\text { environmental problems at the present time? }\end{array}$ & $\begin{array}{l}\text { No / Yes } \\
\text { (five-point scale) }\end{array}$ & $(.78 / .80)$ \\
\hline $\begin{array}{c}\text { awareness of } \\
\text { consequences } \\
\text { (general) }\end{array}$ & $\begin{array}{l}\text { Do you think car use has general undesirable } \\
\text { consequences? }\end{array}$ & $\begin{array}{l}\text { No / Yes } \\
\text { (five-point scale) }\end{array}$ & - \\
\hline $\begin{array}{l}\text { awareness of } \\
\text { consequences } \\
\text { (biosphere) }\end{array}$ & $\begin{array}{l}\text { Do you think car use has undesirable } \\
\text { consequences on the biosphere? }\end{array}$ & No / Yes & - \\
\hline $\begin{array}{c}\text { awareness of } \\
\text { consequences } \\
\text { (social) }\end{array}$ & $\begin{array}{l}\text { Do you think car use has undesirable } \\
\text { consequences with respect to society? }\end{array}$ & $\begin{array}{l}\text { No / Yes } \\
\text { (five-point scale) }\end{array}$ & - \\
\hline $\begin{array}{l}\text { attitude toward car } \\
\text { use }\end{array}$ & $\begin{array}{l}\text { - Do you enjoy car use? } \\
\text { - Do you feel comfortable using a car? }\end{array}$ & $\begin{array}{l}\text { No / Yes } \\
\text { (five-point scale) }\end{array}$ & $.70 / .70$ \\
\hline $\begin{array}{l}\text { subjective norm } \\
\text { (injunctive) }\end{array}$ & $\begin{array}{l}\text { Do you think your family or friends feel a moral } \\
\text { obligation to reduce car use? }\end{array}$ & $\begin{array}{l}\text { No / Yes } \\
\text { (five-point scale) }\end{array}$ & - \\
\hline $\begin{array}{l}\text { subjective norm } \\
\text { (descriptive) }\end{array}$ & $\begin{array}{l}\text { Do your family or friends agree with your } \\
\text { reduction in car use? }\end{array}$ & $\begin{array}{l}\text { No / Yes } \\
\text { (five-point scale) }\end{array}$ & - \\
\hline $\begin{array}{l}\text { belief of necessity } \\
\text { (others) }\end{array}$ & $\begin{array}{l}\text { Do you think that your family or friends believe } \\
\text { that a car is a necessity in daily life? }\end{array}$ & $\begin{array}{l}\text { No / Yes } \\
\text { (five-point scale) }\end{array}$ & - \\
\hline $\begin{array}{l}\text { belief of necessity } \\
\text { (self) }\end{array}$ & $\begin{array}{l}\text { Do you believe that a car is a necessity in daily } \\
\text { life? }\end{array}$ & $\begin{array}{l}\text { No / Yes } \\
\text { (five-point } \\
\text { scale) }\end{array}$ & - \\
\hline $\begin{array}{l}\text { perceived behavioral } \\
\text { control }\end{array}$ & $\begin{array}{l}\text { - Do you think that it takes a lot of effort to reduce } \\
\text { car use? } \\
\text { - Do you think that it is difficult to reduce car use? }\end{array}$ & $\begin{array}{l}\text { No / Yes } \\
\text { (five-point scale) } \\
\text { No / Yes }\end{array}$ & $.70 / .76$ \\
\hline behavioral intention & $\begin{array}{l}\text { - Have you formulated the intention to reduce car } \\
\text { use as much as possible? } \\
\text { - Do you intend to reduce car use as much as } \\
\text { possible? }\end{array}$ & $\begin{array}{l}\text { No / Yes } \\
\text { (five-point scale) } \\
\text { No / Yes }\end{array}$ & $.81 / .84$ \\
\hline $\begin{array}{l}\text { implementation } \\
\text { intention (decision } \\
\left.\text { commitment }^{\dagger}\right)\end{array}$ & $\begin{array}{l}\text { - Do you make an effort to refrain from car use as } \\
\text { much as possible? } \\
\text { - Do you do various things to refrain from car use } \\
\text { as much as possible? }\end{array}$ & $\begin{array}{l}\text { No / Yes } \\
\text { (five-point scale) } \\
\text { No / Yes }\end{array}$ & $.72 / .82$ \\
\hline $\begin{array}{l}\text { behavior } \\
\text { (reported car use } \\
\text { reduction) }\end{array}$ & $\begin{array}{l}\text { - To what extent do you refrain from using a car? } \\
\text { - Do you actually refrain from using a car? }\end{array}$ & $\begin{array}{l}\text { none/ a lot } \\
\text { No / Yes } \\
\text { (five-point scale) }\end{array}$ & $.86 / .87$ \\
\hline
\end{tabular}

${ }^{\dagger}$ As suggested by Fujii (2005), implementation intentions were measured using a measurement for decisional commitment, which is theoretically related to implementation intention. 
Table 2. Mean (M) and standard deviation (STD) for each psychological factor, and $p$ values for one-way analysis of variance (before vs. after survey) of psychological factors assumed in the integrated process model.

\begin{tabular}{|c|c|c|c|c|c|c|}
\hline & \multicolumn{2}{|c|}{ before } & \multicolumn{2}{|c|}{ after } & \multirow{2}{*}{\multicolumn{2}{|c|}{$\mathrm{t}$}} \\
\hline & $\mathrm{M}$ & (STD) & M & (STD) & & \\
\hline habit of car use & 7.45 & $(2.44)$ & 7.25 & $(2.57)$ & 1.56 & \\
\hline general environmental concern & 4.03 & $(0.71)$ & 4.01 & $(0.74)$ & 0.42 & \\
\hline awareness of consequences (general) & 2.06 & $(0.99)$ & 2.29 & $(0.97)$ & -2.86 & ** \\
\hline awareness of consequences (biosphere) & 3.61 & $(1.07)$ & 3.67 & $(0.82)$ & -0.82 & \\
\hline awareness of consequences (social) & 2.79 & $(1.15)$ & 3.01 & $(1.00)$ & -2.71 & *** \\
\hline attitude toward car use & 4.00 & $(0.81)$ & 3.97 & $(0.79)$ & 0.62 & \\
\hline subjective Norm (injunctive) & 3.21 & $(0.82)$ & 3.38 & $(0.83)$ & -2.67 & *** \\
\hline subjective Norm (descriptive) & 2.64 & $(0.92)$ & 2.71 & $(0.85)$ & -0.94 & \\
\hline belief of necessity (others) & 4.44 & $(0.77)$ & 4.35 & $(0.76)$ & 1.54 & \\
\hline belief of necessity (self) & 4.48 & $(0.86)$ & 4.46 & $(0.83)$ & 0.35 & \\
\hline perceived behavioral control & 3.49 & $(1.17)$ & 3.54 & $(1.13)$ & -0.70 & \\
\hline behavioral Intention & 2.77 & $(1.09)$ & 3.08 & $(1.09)$ & -4.28 & $* *$ \\
\hline implementation intention (decision commitment) & 2.30 & $(1.06)$ & 2.71 & $(1.07)$ & -5.89 & *** \\
\hline behavior (self-reported car use reduction) & 2.39 & $(1.23)$ & 2.69 & $(1.17)$ & -4.25 & *** \\
\hline
\end{tabular}


Table 3. Estimated results of path coefficients.

\begin{tabular}{|c|c|c|c|c|}
\hline Path to & Path from & Coefficient & $\mathrm{t}$ & \\
\hline belief of necessity (self) & $\leftarrow$ belief of necessity (others) & 0.12 & 1.72 & * \\
\hline \multirow{11}{*}{ behavioral intention } & $\leftarrow$ habit of car use & -0.09 & -2.54 & ** \\
\hline & $\leftarrow$ general environmental concern & 0.25 & 2.37 & ** \\
\hline & $\leftarrow$ awareness of consequences (general) & 0.17 & 2.73 & *** \\
\hline & $\leftarrow$ awareness of consequences (biosphere) & 0.11 & 1.69 & * \\
\hline & $\leftarrow$ awareness of consequences (social) & 0.02 & 0.27 & \\
\hline & $\leftarrow$ attitude toward car use & -0.15 & -1.63 & \\
\hline & $\leftarrow$ subjective Norm (injunctive) & 0.04 & 0.52 & \\
\hline & $\leftarrow$ subjective Norm (descriptive) & 0.07 & 1.09 & \\
\hline & $\leftarrow$ belief of necessity (others) & -0.07 & -0.82 & \\
\hline & $\leftarrow$ belief of necessity (self) & -0.09 & -1.04 & \\
\hline & $\leftarrow$ perceived behavioral control & -0.07 & -1.15 & \\
\hline \multirow{2}{*}{ implementation intention } & $\leftarrow$ habit of car use & 0.01 & 0.23 & \\
\hline & $\leftarrow$ behavioral intention & 0.55 & 9.75 & $* * *$ \\
\hline behavior & $\leftarrow$ habit of car use & -0.01 & -0.26 & \\
\hline (self-reported car use reduction) & $\leftarrow$ implementation intention & 0.64 & 11.72 & *** \\
\hline habit of car use & $\leftarrow$ & -0.12 & -0.46 & \\
\hline general environmental concern & $\leftarrow$ & 0.05 & 0.50 & \\
\hline awareness of consequences (general) & $\leftarrow$ & 0.16 & 1.01 & \\
\hline awareness of consequences (biosphere) & $\leftarrow$ & 0.04 & 0.29 & \\
\hline awareness of consequences (social) & $\leftarrow$ & 0.14 & 0.88 & \\
\hline attitude toward car use & $\leftarrow$ & -0.11 & -0.95 & \\
\hline subjective Norm (injunctive) & $\leftarrow$ Dummy variables indicate the type of & -0.11 & -0.86 & \\
\hline subjective Norm (descriptive) & $\leftarrow$ TFP experiment. If it is the planning & 0.27 & 1.83 & * \\
\hline belief of necessity (others) & $\leftarrow$ otherwise, it is 0 . & -0.07 & -0.65 & \\
\hline belief of necessity (self) & $\leftarrow$ & 0.11 & 0.94 & \\
\hline perceived behavioral control & $\leftarrow$ & 0.16 & 1.00 & \\
\hline behavioral Intention & $\leftarrow$ & 0.01 & 0.10 & \\
\hline $\begin{array}{r}\text { implementation intention } \\
\text { (decision commitment) }\end{array}$ & $\leftarrow$ & -0.13 & -1.14 & \\
\hline $\begin{array}{r}\text { behavior } \\
\text { (self-reported car use reduction) }\end{array}$ & $\leftarrow$ & 0.14 & 1.28 & \\
\hline
\end{tabular}


Table 4. Estimated direct effects of the effect of the travel feedback program on each factor.

\begin{tabular}{rrr}
\hline & Coef f i ci ent & $\mathrm{t}$ \\
\hline habit of car use & -0.15 & -0.82 \\
general environmental concern & -0.04 & -0.65 \\
awareness of consequences (general) & 0.16 & 1.42 \\
awareness of consequences (biosphere) & 0.04 & 0.41 \\
awareness of consequences (social) & 0.15 & 1.36 \\
attitude toward car use & 0.01 & 0.18 \\
subjective Norm (injunctive) & 0.23 & 2.54 \\
subjective Norm (descriptive) & -0.06 & -0.57 \\
belief of necessity (others) & -0.14 & -1.76 \\
belief of necessity (self) & 0.03 & 0.33 \\
perceived behavioral control & -0.02 & -0.19 \\
behavioral Intention & 0.22 & 2.36 \\
\end{tabular}




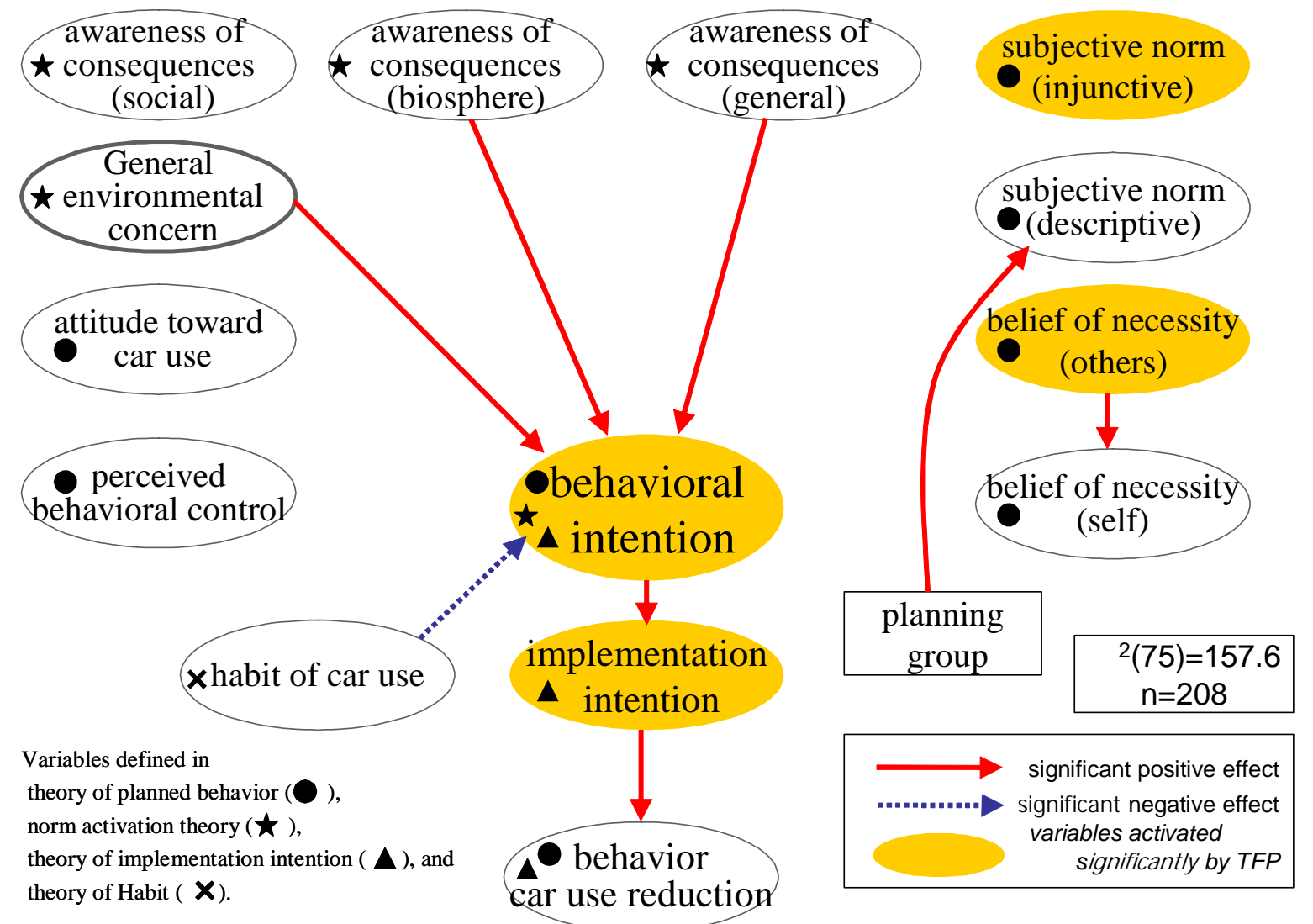

Figure 3. Significant effects shown in the results of the structural equations model. 